PENELITIAN

\title{
Anestesi Spinal Pada Seksio Sesaria Wanita Dengan Tetralogy Fallot Tidak Terkoreksi
}

\section{Spinal Anesthesia For Cesarean Section In Pregnancy With Uncorrected Tetralogy Of Fallot (Tof)}

\author{
Ariati Isabella Siahaan $\triangle^{*}$, Yutu Solihat* \\ *Bagian Anestesiologi dan Terapi Intensif Universitas Sumatera Utara/ RSU Haji Adam Malik, Medan \\ $\triangle$ Korespondensi / correspondence : aans_family@yahoo.com
}

\section{ABSTRACT}

Background: For patients with ToF, pregnancy and childbirth are cause of morbidity (62.5\%) and even mortality (10\%) and real effect to the fetus. Regional anesthesia and general anesthesia can be performed in patients with heart disease, although regional anesthesia spinal anesthesia notably more aggressive lowering the patient's hemodynamic state which can be dangerous, but today there are techniques using low doses of $7.5 \mathrm{mg} 5$ - bupivacaine with opioids as an adjunct to minimize aggressiveness haemodynamic compromise that could harm the patient.

Case: Women 23 years, G1P0A0, weight $48 \mathrm{~kg} 35-36$ weeks pregnant hospitalized due to shortness of breath and seemed to want to give birth. Past medical history was dyspnea from she was child, blue when the activity history and diagnosed congenital heart disease. Spinal anesthesia was performed with bupivacaine 0.5\% low dose of 5 $\mathrm{mg}(1 \mathrm{ml})$ with adjuvant fentanyl $25 \mathrm{mcg}(0.5 \mathrm{ml})$. Block achieved until dermatome thorakal 4.

Conclusion: Spinal block anesthesia technique with a low dose, $1 \mathrm{ml}$, Hyperbaric Bupivacaine $0.5 \%$ plus fentanyl $25 \mathrm{mcg}$ adjuvant considered quite satisfactory as the management of anesthesia in this case. Synergistic effects of local anesthetics and opioids with low dose gives a great advantage to obtain adequate anesthesia, thereby reducing the risk and severity of hypotension.

Keywords: Tetralogy Of Fallot ; Cesarean Section ; Spinal Anesthesia.

\section{ABSTRAK}

Pendahuluan: Bagi pasien ToF, kehamilan dan melahirkan merupakan penyebab morbiditas (62,5\%) bahkan mortalitas (10\%) dan berefek nyata bagi fetus. Anestesia regional dan anestesia umum dapat dilakukan pada pasien dengan penyakit jantung, walaupun regional anestesia terutama spinal anestesia lebih agresif menurunkan keadaan hemodinamik pasien yang dapat membahayakan, namun saat ini ada tehnik 
menggunakan dosis rendah bupivakain 5- 7,5 mg dengan opioid sebagai adjuvan untuk meminimalkan agresifitas penurunan hemodinamik yang dapat membahayakan pasien.

Kasus : Wanita 23 tahun, G1P0A0, berat badan $48 \mathrm{~kg}$ hamil 35-36 minggu dirawat di RS karena sesak nafas dan ingin melahirkan. Riwayat penyakit dahulu sesak saat masih anak -anak, riwayat biru bila beraktifitas dan didiagnosa penyakit jantung kongenital. Digunakan anestesa spinal dengan bupivakain dosis rendah 0,5\% $5 \mathrm{mg}(1 \mathrm{ml})$ dengan adjuvan fentanyl $25 \mathrm{ug}(0,5 \mathrm{ml})$. Blok didapatkan mencapai dermatom thorakal 4.

Lama operasi 30 menit dengan sistolik antara 90-120 mmHg, diastolik antara 55-80 mmHg dan denyut nadi antara 100-112 kali/menit. lahir bayi laki-laki, APGAR 6-7, berat badan 2100 gram. Post operasi pasien dirawat di Intensive Care Unit, dan selama perawatan kondisi hemodinamik stabil.

Ringkasan : Teknik anestesi blok spinal dengan dosis rendah, $1 \mathrm{ml}$, Bupivakain Hiperbarik 0,5\% ditambah dengan adjuvan fentanyl 25 mcg dinilai cukup memuaskan sebagai manajemen anestesi pada kasus ini. Efek sinergis dari anestesi lokal dengan dosis rendah dan opiod memberikan keuntungan besar untuk mendapatkan anestesi yang adekuat, sehingga mengurangi resiko dan tingkat keparahan hipotensi.

Kata Kunci : Tetralogy Of Fallot, Seksio Cesarea, Anesthesi Spinal.

\section{PENDAHULUAN}

Penyakit jantung merupakan penyebab utama kematian maternal pada wanita hamil. Lebih dari $20 \%$ penderita penyakit jantung pada kehamilan mengalami komplikasi seperti gagal jantung, hipertensi, atau aritmia. Komplikasi obstetri dan neonatal lebih banyak dijumpai pada pasien dengan kelainan jantung dibandingkan dengan pasien tanpa kelainan jantung. ${ }^{1}$

Selama kehamilan dan masa nifas, jantung dan sirkulasinya mengalami adaptasi fisiologis. Saat-saat yang paling berbahaya bagi ibu hamil yang menderita penyakit jantung ialah pada kehamilan 32-36 minggu saat terjadi puncak hipervolemia, partus kala II apabila wanita mengerahkan tenaga untuk mengejan, masa post partum karena dengan lahirnya plasenta anastomosis arteri vena hilang dan darah yang seharusnya masuk ke dalam ruang intervillus sekarang masuk ke sirkulasi besar. Komplikasi kehamilan yang berhubungan dengan kelainan jantung antara lain peningkatan insidensi gagal jantung maternal, peningkatan mortalitas ibu, peningkatan risiko kelahiran prematur, angka APGAR yang rendah, dan berat badan bayi lahir rendah.

Faktor resiko terjadi penyakit jantung kongenital pada dewasa adalah 
hipertensi pulmoner, sianosis, operasi ulang, aritmia dan disfungsi ventrikel. Mortalitas operasi meningkat akibat insiden aritmia yang lebih sering terjadi dibandingkan dengan pasien anak. Terdapat abnormalitas sirkulasi pulmoner berupa hipertensi pulmoner akibat pemberian cairan / tekanan yang terlalu banyak, atau alirannya terbatas.

Tetralogi of Fallot (ToF) adalah kelainan jantung kongenital yang terdiri dari ostruksi ventrikel kanan akibat stenosis pulmonalis, vetrikular septal defek (VSD) yang besar, hipertrofi ventrikel kanan, dan overriding aorta. Manifestasi klinis bervariasi dari yang ringan (pink tes) hingga yang berat berupa atresia pulmonal dengan penyumbatan total di ventrikel kanan (RVOT/ right ventricular outflow tract) dan sianosis berat. Sianosis dapat tidak terlihat hingga pasien berusia beberapa bulan setelah lahir, terjadi secara progresif dan memberat setelah itu. Sianosis dapat terlihat sesaat setelah lahir bila terdapat obstruktif total di RVOT. Obstruksi RVOT bersifat dinamis, bergantung pada derajat penyempitan otot infundibular, meningkat pada peningkatan sirkulasi katekolamin baik endogen maupn eksogen. Penurunan resistensi pembuluh darah sistemik mengakibatkan sianosis bertambah berat, yang meningkat secara progresif sejalan dengan waktu.

Saat akan melakukan evaluasi preoperasi, penting untuk mengukur derajat sianosis pasien, saturasi arteri, kadar hematokrit. Kecukupan cairan harus diperhatikan, karena keadaan dehidrasi akan meningkatkan viskositas, penyumbatan pembuluh darah, dan bila pasien memiliki stenosis infundibular, maka akan meningkatkan derajat penyumbatan ventrikel kanan.

Berdasarkan NYHA (New York Heart Association) penyakit jantung dalam kehamilan dibagi dalam 4 kelas. Dimana menurut NYHA kelas I dan kelas II bisa melalui pervaginam, sedangkan kelas III dan IV mempunyai resiko tinggi dalam persalinan pervaginam, karena itu harus dilakukan dengan monitoring ketat. Pasien hamil denganTOF (Tetralogy of Fallot) yang tidak dikoreksi digolongkan kedalam kelas IIa, sedangkan dengan TOF yang dikoreksi menjadi kelas I.

\section{KASUS}

Seorang wanita hamil umur 23 tahun G1P0A0, berat badan $48 \mathrm{~kg}$ dengan usia kehamilan 35-36 minggu dengan TOF datang ke rumah sakit dalam keadaan sesak napas dan mulesmules mau melahirkan yang ditandai dengan keluarnya lendir cairan campur darah. Yang akan dijadwal untuk segera dilakukan tindakan emergensi seksio sesaria. Sesak dirasakan semakin memburuk satu hari sebelum masuk rumah sakit.

Pada pemeriksaan fisik, pasien merasa lebih nyaman dan tenang dengan posisi tidur setengah duduk, 
dengan laju nafas 26-30 kali per menit, dan saturasi oksigen dengan menggunakan nasal kanul 2 liter adalah $75-80 \%$. Denyut nadi sebelum operasi berkisar antara 100-120 kali per menit reguler, tekanan darah 130/80 $\mathrm{mmHg}$, suara jantung sistolik murmur. Gambaran echokardiografi menunjukkan suatu TOF dengan Ejection Fraction 63\%. Investigasi hematologi dan profil perdarahan normal dengan nilai hematokrit 50\% (Hb: 15,2 gr\%).

Sebelum dilakukan pembiusan pasien diberi cairan kristaloid $500 \mathrm{ml}$ RL secara perlahan sebagai preload cairan. Pembiusan dilakukan dengan teknik blok spinal pada level L3-L4 dengan menggunakan jarum spinal 25 $G$ tipe quincke. Obat pilihan yang digunakan adalah dosis rendah bupivakain hiperbarik 0,5\%, 1ml, ditambah adjuvan fentanyl $25 \mathrm{mcg}$ ke rongga subarachnoid. Tinggi blok diatur setinggi Th4 dengan tes pinprick.

Lahir seorang bayi laki-laki dengan BB: 2,1 kg, PB: $45 \mathrm{~cm}$ dengan skor APGAR 1 menit pertama: 6-7 dan 5 menit kedua: 8-9. Tekanan darah sistolik selama operasi berkisar antara 90-120 mmHg dan tekanan darah diastolik berkisar antara 55-80 $\mathrm{mmHg}$, denyut nadi berkisar antara 100-112 kali/menit. Perdarahan selama pembedahan berkisar sekitar $200 \mathrm{ml}$ dengan urin output $50 \mathrm{cc} / \mathrm{jam}$. Selama operasi diberikan Oksitosin 10 IU yang diberikan secara lambat melalu jalur iv setelah bayi lahir. Post operasi pasien dirawat di ICU dengan terapi multimodal analgesia yaitu kombinasi NSAIDs dan opioid (Fentanyl $400 \mathrm{mcg}$ dalam 50 cc $\mathrm{NaCl} \quad 0,9 \% \quad 6-8 \quad \mathrm{cc} / \mathrm{jam}$ melalui syringe pump). Pemantauan selama di ICU, hemodinamik relatif stabil dan pasien dipindahkan ke ruangan 4 hari post operasi.

\section{PEMBAHASAN}

Kehamilan dengan penyakit jantung merupakan penyebab kematian maternal non-obstetrik yang cukup tinggi. Kehamilan sendiri dapat menjadi beban sirkulasi terutama karena beban volume yang memberi pengaruh yang signifikan terhadap kondisi kesehatan ibu. Dalam menghadapi sekuel setelah dikoreksi maupun yang belum dikoreksi, dapat menjadi beban yang mengganggu kesehatan ibu dan janinnya.

Penyakit jantung kongenital pada ibu hamil menyebabkan hipoksemia residual berkaitan dengan perkembangan janin yang buruk, tingkat aborsi spontan yang tinggi, persalinan prematur, dan peningkatan kejadian komplikasi janin.

TOF adalah bentuk kelainan jantung yang paling sering dijumpai pada usia dewasa dengan angka kejadian 5-8\% dari semua kelainan jantung kongenital. Kelainan pada TOF meliputi stenosis pulmonal berat atau valvular, VSD besar, hipertrofi ventrikel kanan dan overriding aorta. Sebelum dilakukan koreksi, gejala yang 
sering timbul adalah sesak napas dan sianosis. Kehamilan pada TOF yang belum dikoreksi tidak dianjurkan dengan resiko kematian ibu mencapai 15\% dan kematian janin 30\%.

Komplikasi yang dapat terjadi seperti aritmia dan gagal jantung kanan dapat terjadi, terutama bila ada residual shunt, obstruksi aliran ventrikel kanan, dan hipertensi pulmonal. Penurunan resistensi vaskuler sistemik dan peningkatan curah jantung yang terjadi pada kehamilan dapat meningkatkan pirau dari kanan ke kiri. Dianjurkan untuk dilakukan penilaian jantung secara teratur selama kehamilan pada TOF yang telah dikoreksi maupun tidak.

Prognosis semakin buruk bila hematokrit ibu lebih dari 60, saturasi oksigen kurang dari $80 \%$ dan hipertensi ventrikel kanan dengan tekanan lebih dari $120 \mathrm{mmHg}$.

Dewasa ini, anestesia regional lebih sering dilakukan daripada anestesia umum untuk tindakan seksio sesarea. Anestesi regional memungkinkan ibu hamil tetap sadar dan turut berpartisipasi dalam kelahiran bayi tanpa memberikan komplikasi fatal seperti pada pemberian anestesia umum. Walaupun hipotensi akibat penurunan resistensi vaskular sistemik yang merupakan akibat dari blokade serat simpatetik preganglion masih menjadi masalah dengan blok neuroaksial, aksi sinergis dari anestesi lokal dan opioid memberikan keuntungan besar, yaitu mendapatkan efek anestesi adekuat dengan dosis anestesi lokal yang lebih rendah sehingga mengurangi risiko dan keparahan hipotensi.

Hipotensi yang terjadi karena penurunan tahanan vaskular sistemik akibat hambatan simpatis tetap menjadi sebuah permasalahan tersendiri. Keadaan ini dapat membahayakan ibu maupun bayi. Hipotensi berkaitan dengan tingginya blokade spinal. Semakin tinggi blokade spinal, mekanisme kompensasi akibat hambatan simpatis pun semakin ditekan. Angka kejadian hipotensi akibat anestesi spinal pada pasien bedah sesar bervariasi dan cukup tinggi.

Tujuan anestesi yaitu memperoleh level blokade adekuat dengan kombinasi anestesi spinal dosis rendah ditambah adjuvant fentanyl tidak begitu mempengaruhi hemodinamik, dengan dosis anestesi lokal yang rendah dapat mengurangi efek samping dan penambahan adjuvant menambah potensiasi analgesi. Hipotensi pada sebagian pasien dapat mencetuskan iskemia miokard, dan takikardi akan menyebabkan peningkatan konsumsi oksigen serta menurunkan waktu pengisian ventrikel kiri dan akan memperburuk keadaan hipertensi pulmonal. Tujuan manajemen cairan sebelum dilakukan tindakan anestesi spinal adalah menjaga keadaan normovolemia karena hipervolemia akan menyebabkan edema paru dan hipovolemia akan 
menurunkan preload.

Anestesia regional selama persalinan direkomendasikan untuk mengurangi peningkatan lanjut dari curah jantung dan kebutuhan oksigen otot jantung yang diakibatkan nyeri dan kecemasan.

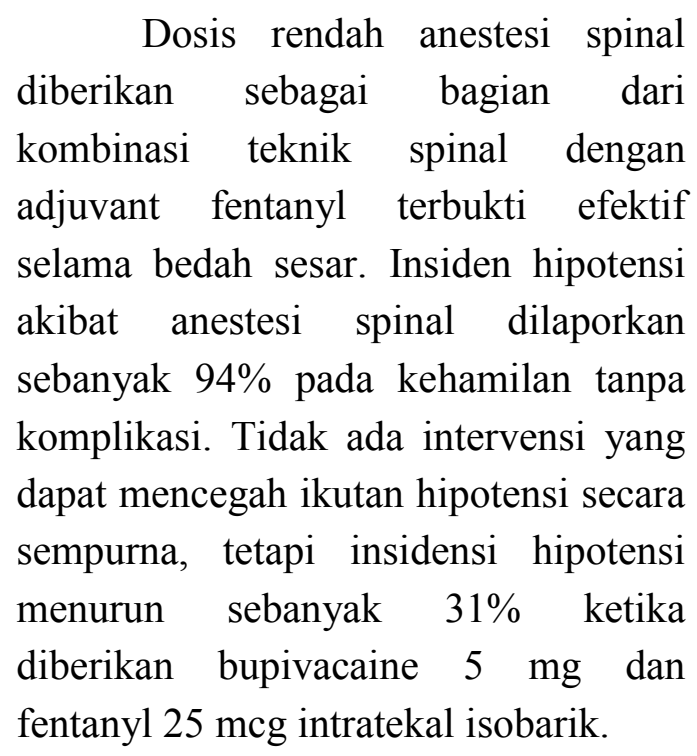

\section{KESIMPULAN}

Teknik anestesi blok spinal dengan dosis rendah, $1 \mathrm{ml}$, Bupivakain Hiperbarik 0,5 \% ditambah dengan adjuvan fentanyl $25 \mathrm{mcg}$ dinilai cukup memuaskan sebagai manajemen anestesi pada kasus ini. Efek sinergis dari anestesi lokal dengan dosis rendah dan opiod memberikan keuntungan besar untuk mendapatkan anestesi yang adekuat, sehingga mengurangi resiko dan tingkat keparahan hipotensi.

\section{DAFTAR PUSTAKA}

1. Heidemann BH, McClure JH. Changes in maternal physiology during pregnancy. Continuing Education in Anesthesia, Critical Care and Pain, $2003 ; 3: 65-68$

2. Rosen MA. Management of Anesthesia for the Pregnant Surgical Patient. Anethesiology 1999; 91: 1159-63

3. Freeman WK, Gibbons RJ. Perioperative cardiovascular Asessment of Patients undergoing non cardiac surgery. Mayo Clin Proc. 2009; 84(1) : 79-80 